\title{
Mapping Multi Stakeholder Roles on Fire Management in Conservation Areas of Kuningan Regency
}

\author{
Indriani Ekasari ${ }^{1}$, Ronggo Sadono ${ }^{2 *}$, Djoko Marsono ${ }^{3}$, Joko Ridho Witono $^{4}$ \\ ${ }^{1}$ Doctoral Study Program, Faculty of Forestry, Universitas Gadjah Mada, Jl Agro No 1, Bulaksumur, Sleman, Yogyakarta \\ 55281 \\ ${ }^{2}$ Department of Forest Management, Faculty of Forestry, Universitas Gadjah Mada, Jl Agro No 1, Bulaksumur, Sleman, \\ Yogyakarta 55281 \\ ${ }^{3}$ Department of Forest Resources Conservation, Faculty of Forestry, Universitas Gadjah Mada, Jl Agro No 1, Bulaksumur, \\ Sleman, Yogyakarta 55281 \\ ${ }^{4}$ Research Center for Plant Conservation and Botanic Gardens - Indonesian Institute of Sciences, Jl Ir. H. Juanda no 13, Bogor, \\ Jawa Barat 16122
}

Received March 29, 2020/Accepted November 6, 2020

\begin{abstract}
Forest fire was a persistent concern management in conservation areas of Mount Ciremai National Park (MCNP) and Kuningan Botanical Garden (KBG). Many of the forest fire was sparked by anthropogenic ignitions like careless fire use for extracting forest honey. This study aims to map multi stakeholder roles on fire management in conservation areas. Twenty-seven actors were interviewed to learn who are the fire actors and network. These multi stakeholders included government officials, local businessmen, non-governmental organizations and community members. Study site and data collection were carried out in seven villages around conservation areas from July to September 2019. The relationships between the actors were analyzed with the software Node XL Basic and Gephi 9.0.2 using the Social Network Analysis. Our results identify close relationships and strong connections to all actors of more than half $(63.2 \%)$ but social or personal approach between all actors were still required. Head of MCNP, Head of KBG and Head of AKAR (Aktivitas Anak Rimba) acted as the important actors. To prevent the area from further fire occurrences, management authorities should establish mutual confidence and make other actors believe that heads of conservation areas are a solid team to prevent conservation areas from burning.
\end{abstract}

Keywords: forest fire, Kuningan Botanical Garden, Mount Ciremai National Park, social network analysis

*Correspondence author, email: rsadono@ugm.ac.id, tel./fax.+62-274-548815

\section{Introduction}

Fire is one of the most frequent disturbance in Indonesian conservation areas, particularly during the dry season (Whitmore, 1988; Purnomo et al., 2017). Wildfires have significant environmental effects, including a reduction in biodiversity and soil fertility, leading to micro and global climate change. Additionally, the smoke from the fires had numerous negative socio-economic impacts, affects public health such as respiratory disorders, harmful to land, water and air, also disrupts the political relationships both nationally and internationally (Pinto et al., 2017; Purnomo et al., 2017; Rosales-Rueda \& Triyana, 2018). Even fire in the conservation area of the United States and Indonesia might be misinterpreted and damage institutional cultures with different sets of wildfires or wildfire management motives (Fischer et al., 2013; Panjaitan et al., 2019).

The availability of fuel, the atmosphere, and the caused of ignition influence the incidence of fire. In addition to landscape as an abiotic factor, other abiotic factors such as topography, vegetation and climate have been established to assess spatial fire patterns (Febriandhika et al., 2018). Besides abiotic factors, the main cause of Indonesia's forest fires is the close link between poverty and fire at the village next to conservation area (Edwards et al., 2020). Many of the fire in China's forest was triggered by anthropogenic combustion, which was closely linked to residential distribution and development modes (Tian et al., 2013). The density of fires near human settlements is high although overall contribution of fires near settlements is low in Indonesia (Cattau et al., 2016). Community settlement near fire areas is at risk of significant losses such as burnt houses and property. For example, forest fires in Australia caused 28 people to die and 3000 homes were destroyed or damaged from July 2019 to January 2020 (Yeung, 2020). Fires have also recurred in the Mount Ciremai National Park (MCNP) and Kamojang Crater Nature Reserve (KKNR) conservation 
areas in Java, Indonesia, causing ecological and economic losses. The reason of fire in the MCNP and KKNR conservation area in West Java is human activities such as agricultural land preparation, sand mining, and illegal bird poaching (Hadiprasetya, 2009; Lestari et al., 2019). Significant losses and the negative impacts of forest fires would elicit strong and severe reaction from Indonesian policymakers (Panjaitan et al., 2019). The government of Indonesia must consider the impact of fires by developing an air quality warning system to limit exposure to air pollution, especially for young children and expectant mothers (Rosales-Rueda \& Triyana, 2018). Local community participation has become one of the alternative solutions to fire danger in Australia and Switzerland, but more support and hard work is still needed to win community to mitigate the fire (Eckerberg \& Buizer, 2017).

Kuningan Regency, West Java, has two conservation areas, including MCNP as an in-situ conservation area and Kuningan Botanical Garden (KBG) as an ex-situ conservation area. Both conservation areas were located side by side, but with separate management authorities. MCNP is managed by the Ministry of Environment and Forestry (central government) and KBG is managed by the Kuningan Regency Environmental Agency (local government). All conservation areas have a history of frequent fires which becomes an annual problem for management authorities. Panjaitan et al. (2019) suggest that, although there was a major interaction between the role of central and local government to govern forest fire prevention, forest fires still occur every year in the conservation areas. Therefore, multi stakeholders are needed to work together to minimize forest fire.

The multi stakeholder updates their values and behavioral goals through social interaction, which in turn affects how the social group adapts to their environment (Fischer et al., 2013). The distance from community settlement also has an effect on fire severity. Most of the people who live around conservation areas want to be involved in management to sustain their economy. Utilizing spatial trend analysis, a research in China found that forest fires mostly occurred in sparsely populated areas of over 100 people $\mathrm{km}^{2}$ and less than $1 \mathrm{~km}$ away from resettlement to conservation areas (Tian et al., 2013). On the other hand, Cattau et al (2016) stated that relatively few hotspots are located in $5 \mathrm{~km}$ of settlement in Indonesia, but it is possible that other types of land use contribute substantially to the fire landscape. In addition, stakeholders promote discussion of diverse landscapes (Fischer et al., 2013). Multi stakeholders have an important role in raising potential fire danger. Therefore, there is a needto map these stakeholder positions. Social Network Analysis (SNA) is a valuable method to analyze multi stakeholder mapping functions and flow structure. SNA provides quantitative measurements of the presence, directionality, and strength of relations between the actors in the network and opportunities for knowledge or services exchange (Wasserman \& Faust, 1994). A social network consists of a finite group of actors and their relationships or partnerships. Social networks are a particular form of social capital that individuals can employ to enhance their advantages and opportunities (Scott, 2017). SNA is a study of social structure and growth from a relational perspective to define and draw analysis of inter-firm relationships that form the inferences of project coalition (Pryke, 2004; Lovric et al., 2018).

Descriptive SNA indices to analyze the overall structure of the network and the role of key actors in identifying the two main focus areas of networks and the actors or nodes. Actors or individuals who live around these two conservation areas are considered to have strong relationship related to conservation areas management. SNA portrayed the mapping and measuring of relationships and flows between individuals, groups, organizations, or societies (Wasserman \& Faust, 1994; Milovanović et al., 2019). The actors in SNA portray as a network of permanently connected nodes or transitory configurations. Such node networks are connected by relational links which could take several forms (Wasserman \& Faust, 1994). A significant action to explain in terms of their place within the relationship network is to map the role of the actors using SNA in reducing fire in conservation area research. The principal method built to research control through SNA is the idea of centrality. Degree, closeness, and betweenness centrality characterize actors locations in terms of how close they are with the center of a network activity (Purnomo et al., 2017). The meanings of single centrality have been defined as a degree centrality referring to the number of nodes connected to an organization. This measure considers both out-degree (the number of going to other nodes) and in-degree (the number of incoming edges), since the network graph is directed. As they are in touch with many others, nodes with a high degree centrality could be considered well connected (Giurca \& Metz, 2018). Closeness centrality tests the number of steps (tasks/ relations) required for a given actor to reach any other actor in the network. Betweenness centrality tests to what degree a particular node lies on the shortest paths between many other nodes in the graph (Freeman, 1977). The more paths on a node means a node has become more significant than others (Hadiana \& Witanti, 2017). The aim of this study is to map multi stakeholder roles on fire management in conservation areas.

\section{Methods}

This study was done in a qualitative manner of the actors to describe the daily activities in accessing the social, human, financial, physical, and natural capital. Meanwhile, the data was collected through in-depth interviews, observations, and document studies. The study equipment required map of villages around conservation areas, demography data, questioner sheets, and voice recorders. Field data were gathered as study sites from seven villages in three subdistricts in Kuningan Regency, West Java Province. Padabeunghar, Kaduela, and Pasawahan Villages are in Pasawahan Sub-district; Cibuntu, Trijaya, and Seda Villages are in Mandirancan Sub-district; and Setianegara Village in Cilimus Sub-district. Study locations were chosen based on a variety of factors, represented the highest and most regularly fire events from year 2012 to 2018 . The other reasons were many of the villagers are doing farm activities and collecting forest honey.

Since the number of actors was not definite (Manik et al., 
2018), the study provided data on the individual case network attributes for the estimation of overall network parameters (Scott, 2017). The twenty-seven actors as nodes who were interviewed including government officials ( 7 people), local businessmen (3 people), NGO/ non-governmental organizations (3 people) and community members (14 people). The nodes were responsible individuals involved in mitigating forest fire and community fire issues (MPA/Masyarakat Peduli Api, volunteer communities who concern with fire). The field observations were performed from July through September 2019.

Starting point for mapping of multi stakeholder role using SNA required the pattern of social networks to obtain the relationship of all actors in graph. A graph is simply a series of connecting pointsdepicting individuals with lines indicating their relationships with each other (Scott, 2017). The SNA graph could be described as a sociogram representing an example of a directed graph which consisted of four actors (A, B, C, D) connecting one another (Figure 1). This construction of signed and directed graphs was used to analyze group structure from each member point of view simultaneously and not just from a particular focal individual point of view (Scott, 2017). The mapping method was a much more diverse and analytical approach that included flow maps, cognitive mapping and an overview of accountability. Perhaps a way of incorporating any hint of roles and relationships to what would otherwise be a portrayal of the structure without details on actor position (Pryke, 2004). Sociogram helped to demonstrate a model of social networking between actors or organizations to mapping and analyzing their role (Figure 2).

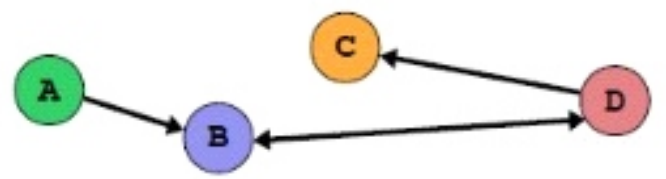

Figure 1 Sociogram on social network analysis includes four actors A, B, C, and D were connected each others.

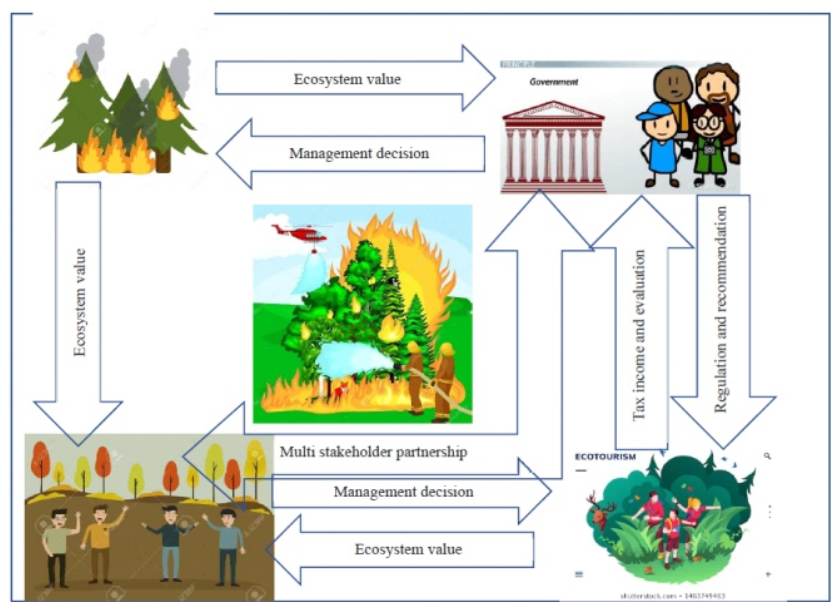

Figure 2 Conceptual design social network model for forest fire.
Furthermore, SNA described the position of the actors in directing their relationships using a numerical matrix. Every actor had one column and one row. Each row in this sociomatrix is the relationship actor $i$ give to all other actors (j's). The SNA was achieved by generating paired actors with square binary matrices. These matrices covered the exchange of information between actors with ' 1 ' used to indicate important exchange of information and ' 0 ' when there was no significant exchange of information (Purnomo et al., 2017). This stages of working to mapping of the role of multi stakeholder in conservation areas has been described as in Figure 3.

In order to explore connections at a local level, all nodes were also questioned about their ties or relationship or edges to others. SNA was run using software Node XL Basic and Gephi 0.9.2. The network could be evaluated in terms of network density, degree centrality, closeness centrality, and betweenness centrality. The overall level of connectivity in a network was density. A complete graph has a density of $100 \%$, conventionally expressed as 1.0 . A graph that contains half of all potential connections has a density of $50 \%$ or 0.5 , and the density ranges from 0 to 1.0. For the directed graph the density formula was shown in Eqution [1] (Scott, 2017).

$$
\mathrm{D}=\frac{\sum \mathrm{l}}{n(n-1)}
$$

note: $\mathrm{D}=$ network density, $\sum \mathrm{l}=$ total lines present, and $\mathrm{n}=$ total node in the network.

A higher score suggested that only a few actors affected the network, and a lower score suggested that actors within the network had identical relationship numbers (Huang et al., 2019). The Equation [2] could be defined for calculating the degree centrality of a node and the normalized degree centrality (Freeman, 1977).

$$
C_{D}(n)=\sum \frac{d i}{N-1}
$$

note: $C_{D}=$ the degree centrality of a node, $d i=$ the number of relations on a node, $N=$ total node in the network, and $n=$ an actor.

Closeness referred to measure the path number from one actor to reach the targeted actor using network (Brass, 1984), or as path numbers to tie an actor to all actors in the network. The Equation [3] to calculate the closeness centrality of a node and normalized closeness centrality could be defined (Freeman, 1977).

$$
C_{c}(n)=\frac{N-1}{\sum_{t \neq v \in V} d_{f}(V, t)}
$$

note: $\mathrm{d}_{\mathrm{f}}=$ the shortest distance between two nodes (from $\mathrm{V}$ to $\mathrm{t}), N=$ the number of relations on an actor, and $n=$ an actor.

Betweenness centralization expressed the degree to which a few organizations control the relationships for other organizations in the network. The betweenness centrality of node $\mathrm{n}$ can be expressed as shown in Equation [4] (Freeman, 1977).

$$
C_{B}(n)=\frac{\sum \sigma_{s t}(n)}{\sum_{s \neq n \neq t} \sigma_{s t}}
$$

note: $\sigma_{s t}=$ the total number of the shortest paths, $\sigma_{s t}(n)=$ the number of shortest paths passing through $n$, and $n=$ an actor. 


\section{Results and Discussion}

This study analyzed the occurrence of fire in MCNP and KBG conservation areas since 2012 to 2018 (Figure 4). At that time, the largest effect of fire was 1213.55 ha for MCNP in 2018, and 30 ha for KBG (TNGC, 2018; KRK, 2019). There are 54 villages in 12 sub-districts in 2 regencies (Kuningan and Majalengka) across two conservation areas but the disaster of fire occurred almost at the same location in seven villages (study sites). This close together of location of these villages could be an effective strategy to search for social structures and recognize the roles of multi stakeholder institutions across conservation areas. Using SNA helps to examine the relationship basis on social phenomena and social structure, and to identify the most powerful actors in the network (Huang et al., 2019).
The highest percentage of actors as multi stakeholder included heads of villages and (heads of) farmers, they were all of MPA members who played a very important role in extinguishing and mitigating fire disaster (Table 1). Fire existed within conservation areas was handled by MCNP fire fighters, KBG fire fighters (Singgalen et al., 2019), and community. A review of the interviews showed actors often blame each other for causing fires. Government officials said the fires had been caused by communities. While communities blame the governments for having absolute control over conservation areas. In this case, communities feel can no longer participate to gain more profit from conservation areas. Based on field data, the actors stated that fires were mainly caused by community activities such as extracting forest honey, burning waste at the edge of

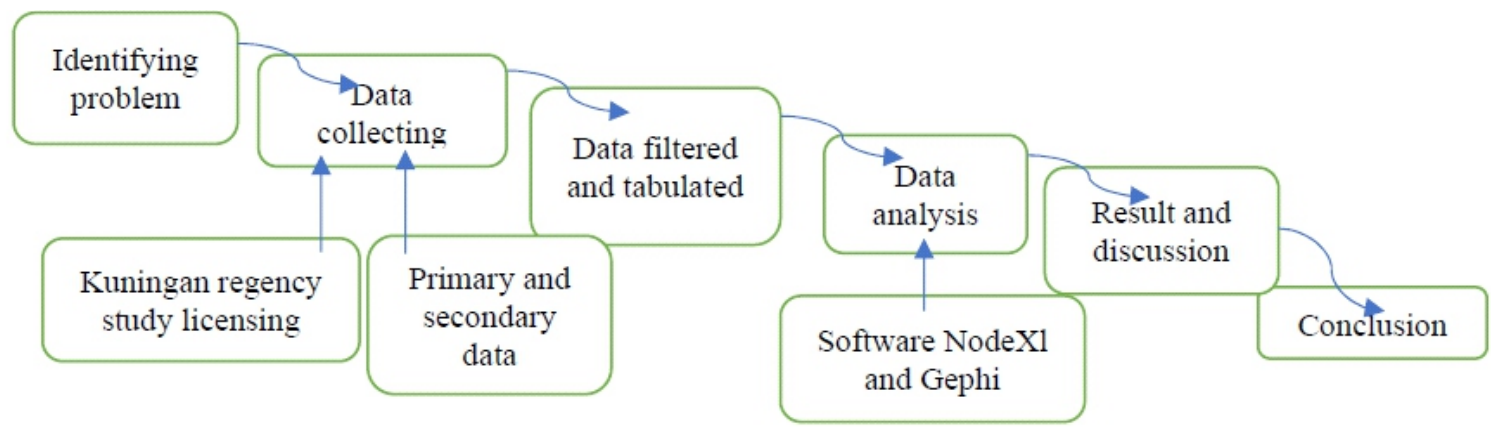

Figure 3 Study mindset of social network of multi stakeholder on conservation areas.

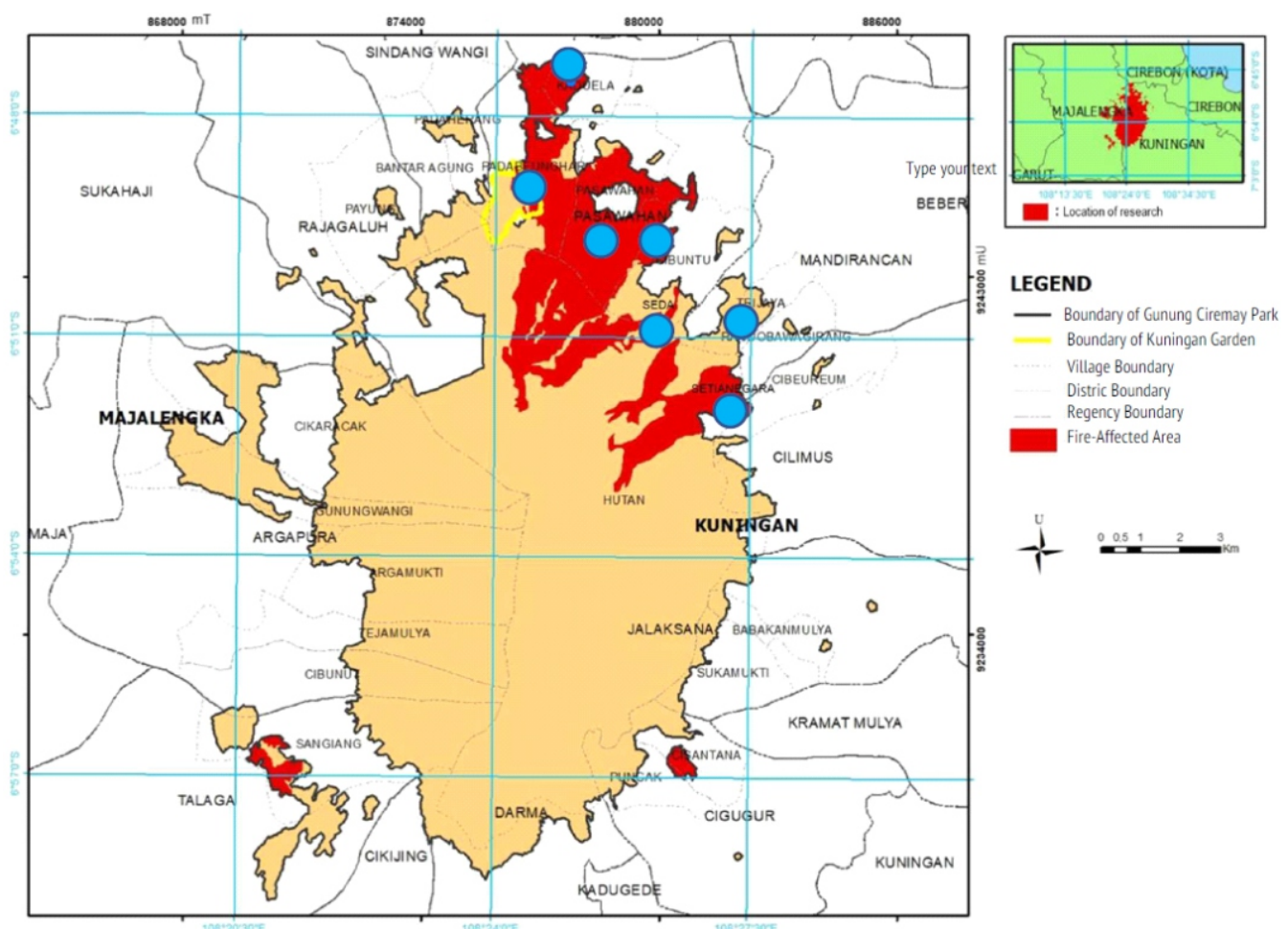

Figure 4 Map of research study on seven villages around Mount Ciremai National Park and Kuningan Botanical Garden conservation area. The seven villages were presented in blue dots and the red color indicated the fire-affected area in 2018. 
Table 1 Actor profile on mapping of multi stakeholder role in conservation area using social network

\begin{tabular}{|c|c|c|c|}
\hline Actors & Nodes & $\begin{array}{c}\text { Sum } \\
\text { (person) }\end{array}$ & $\begin{array}{l}\text { Percentage } \\
\quad(\%)\end{array}$ \\
\hline \multicolumn{4}{|l|}{ Government officials } \\
\hline 1. Head of Mount Ciremai National Park & $\# 1$ & 7 & 25.925 \\
\hline 2. Head of Pasawahan Resort, Mount Ciremai National Park & \#2 & & \\
\hline 3. Head of West Java Province Environmental Agency & \#3 & & \\
\hline 4. Head of Kuningan Regency Environmental Agency & \#4 & & \\
\hline 5. Head of Kuningan Botanical Garden & $\# 5$ & & \\
\hline 6. Head of Kuningan Regency Regional Planning Agency & \#6 & & \\
\hline $\begin{array}{l}\text { 7. Head of Kuningan Regency Regional Disaster } \\
\text { Management Agency }\end{array}$ & $\# 7$ & & \\
\hline \multicolumn{4}{|l|}{ Local businessmen } \\
\hline 1. Kuningan Regency regional owned enterprises & \#8 & 3 & 11.111 \\
\hline 2. Local entrepreneur 1 & \#9 & & \\
\hline 3. Local entrepreneur 2 & $\# 10$ & & \\
\hline \multicolumn{4}{|l|}{ Non-Governmental Organizations } \\
\hline 1. Head of AKAR (Aktivitas Anak Rimba) & \#11 & 3 & 11.111 \\
\hline 2. Head of Ciremai Forum & \#12 & & \\
\hline 3. Head of Kanopi & $\# 13$ & & \\
\hline \multicolumn{4}{|l|}{ Community members } \\
\hline 1. Head of Pasawahan Village & $\# 14$ & 14 & 51.851 \\
\hline 2. Head of Kaduela Village & \#15 & & \\
\hline 3. Head of Padabeunghar Village & \#16 & & \\
\hline 4. Head of Trijaya Village & \#17 & & \\
\hline 5. Head of SetianegaraVillage & \#18 & & \\
\hline 6. Head of Seda Village & \#19 & & \\
\hline 7. Head of Cibuntu Village & \#20 & & \\
\hline 8. Farmer of Pasawahan Village & \#21 & & \\
\hline 9. Farmer of Kaduela Village & \#22 & & \\
\hline 10. Farmer of Padabeunghar Village & \#23 & & \\
\hline 11. Farmer of Trijaya Village & \#24 & & \\
\hline 12. Farmer of SetianegaraVillage & \#25 & & \\
\hline 13. Farmer of Seda Village & \#26 & & \\
\hline 14. Farmer of Cibuntu Village & \#27 & & \\
\hline Total & & 27 & 100 \\
\hline
\end{tabular}

conservation areas, and throwing burned cigarette butts. The governments have a lack of desire and capacity to enforce laws for people who cause forest fires deliberately or unintentionally. Previous studies have found similar cases where actors often blame each other for causing forest fire in the province of Riau, Indonesia and also in Kalasha Valley, Pakistan (Purnomo et al., 2017; Zeb et al., 2019).

Despite the fire occurs almost every year, local businessmen still decided to create ecotourism sites around the fire-affected area. For example, two local businessmen used their own funds to create ecotourism sites. The conservation areas can be preserved to sustain community economy development. The local communities also often regularly patrol around their ecotourism area and MCNP area. Communities around $\mathrm{MCNP}$ and $\mathrm{KBG}$ required livelihood so they tend to become ecotourism entrepreneurs while farming in conservation areas was prohibited. Singgalen et al. (2019) said that, while mobilizing access to some types of resources, tourism affected people livelihood around the tourist destinations. Node\#12 (head of Ciremai Forum) was the head of a discussion group created by local government, private companies and communities around the conservation areas. This platform offers node\#1 (head of Mount Ciremai National Park) suggestion for a qualified individual or organization in conservation areas as an ecotourism entrepreneur. Node\#11 (head of AKAR, Aktivitas Anak Rimba) and node\#13 (head of Kanopi) were a nature-loving NGO, the relationship between node\#11 and the communities was very close and all of MPA members knew node\#11 as fire fighters. Node\#11 and his other NGO partners from other districts are always able to extinguish the forest fire occurrences. Multi stakeholder responsibilities mapping appears to be a positive arrangement since almost every year in the same location occurs fire. Similar findings found by Fischer et al. (2013) where wildfire links social and ecological structures in the United States dry-forest environment appeared to be strong. The cooperation between organizations seems lacking, presenting many management challenges such as maladaptive management behaviour.

Data analysis using the directed graph of Node XL Basic that represented in drawn form. The directed graph was shown by adding an arrow head to each line. Overall metrices of mapping of multi stakeholder role in conservation area using social network (Table 2). The arrow direction indicates the direction of the relationship in the graph (Scott, 2017). There were 27 vertices, indicating that this analysis had 27 actors or nodes to evaluate and that the 
27 actors had 445 nodes (ties) to link. The maximum geodesic distance (diameter) was 3 and the geodesic average was 1.311. This means 3 vertices (paths) were the longest distance from one node to the target node. The network density showed more than half (63.2\%), which implies that the connection between 27 nodes was high. The strength relationship was all about the high confidence to reduce the occurrence of fire among 27 nodes. This means that there is a need of more intense for social or personal approach from government officials to members of the community because fire still occurs every year (Figure 5). Due to a lack of knowledge about conservation area, this study also found several community members who said they did not understand what the conservation area and their functions. In addition to the government officials, private sectors and community members have made government wheels work according to the principles of good governance to promote the implementation of the public policy (Panjaitan et al., 2019) like forest fire mitigation. Integrated social and

Table 2 Overall metrices of mapping of multi stakeholder role in conservation area using social network

\begin{tabular}{ll}
\hline \multicolumn{1}{c}{ Graph metric } & Value \\
\hline Graph type & Directed \\
Vertices & 27 \\
Unique edges & 445 \\
Edges with duplicate & 0 \\
Total edges & 445 \\
Connected components & 1 \\
Maximum vertices in a connected component & 27 \\
Maximum edges in a connected component & 445 \\
Maximum geodesic distance (diameter) & 3 \\
Average geodesic distance & 1.311 \\
Graph density & 0.632 \\
\hline
\end{tabular}

ecological modeling systems were especially valuable tools for understanding the causes of the climate and human behavior consequences (Fischer et al., 2013).

The mapping of 27 nodes and node\#3 (head of Java Province Environmental Agency) was the most distant node from the rest (Figure 6). Node\#3 had only collaboration work with node\#4 (head of Kuningan Regency Environmental Agency) and node\#5 (head of Kuningan Botanical Garden) but no connection to the other 24 nodes. This coordinating work was effective when fire did not affect the KBG area in 2019. Node\#1 and node\#11 were in this network center location, meaning they had central nodes among the other nodes for this network. Collaborative functions between the nodes would be the positive advantage for reducing fire in conservation areas. Based on Panjaitan et al. (2019), the role of local and central government officials played in reducing fire had a major impact, although not a direct effect. In reality, they still required the other nodes role.

Degree centrality Degree centrality indicates that individuals with more connections in a network may have larger influence in that network (Huang et al., 2019). In Table 3, it can be seen that the degree centrality were occupied by node\#11 (head of AKAR, Aktivitas Anak Rimba) and node\#1 (head of Mount Ciremai National Park). Node\#1 was an actor in the government and node\#11 was an actor in the NGO. They had a good influence and the other nodes were able to have a friendship with these two nodes. High degree centrality means the relative extent to which one node is involved in interactions with the rest of the party. In a sense of human communication networks, the choice of degree centrality has been rationalized above (Pryke, 2004). This situation should be an advantage for management authorities

Fire-affected area in Mount Ciremai National Park and Kuningan Botanical Garden

(ha)

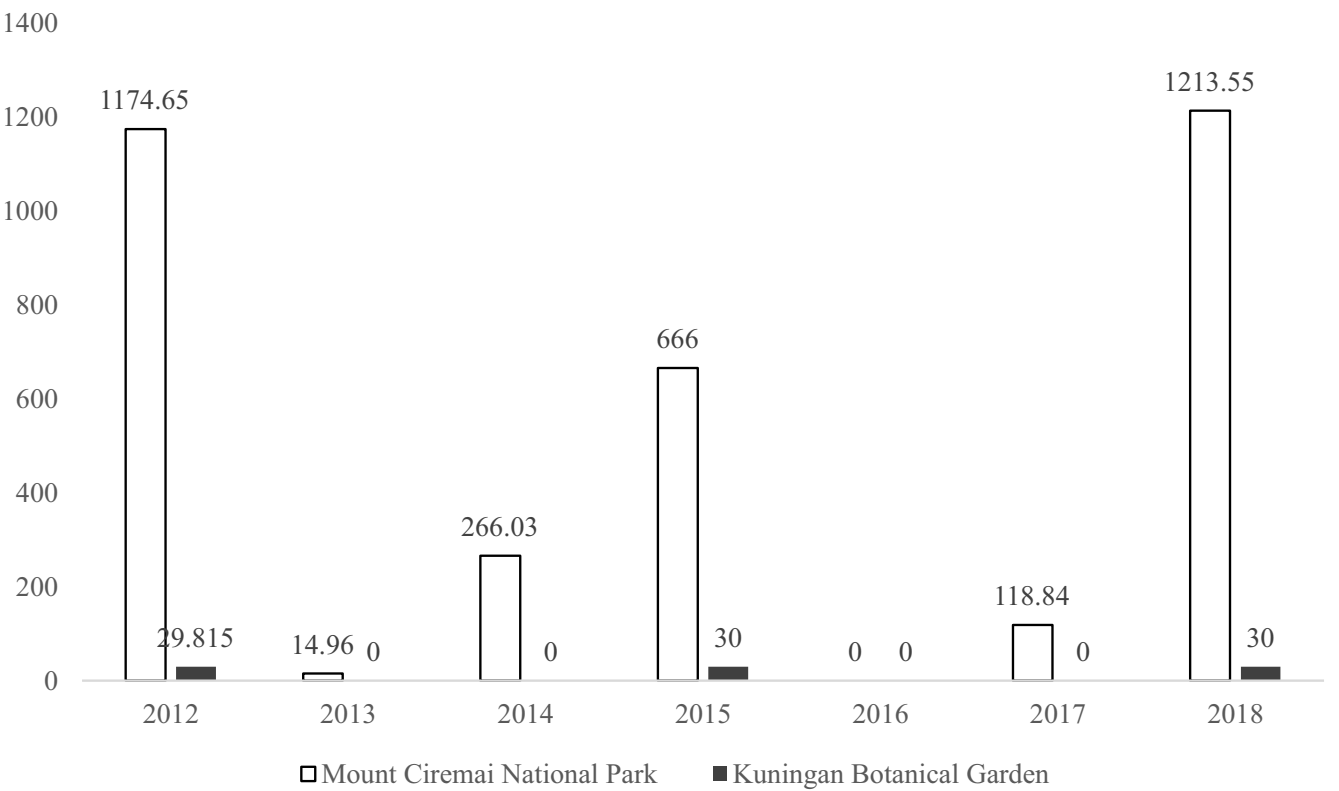

Figure 5 Fire-affected area of Mount Ciremai National Park and Kuningan Botanical Garden since 2012 to 2018. 


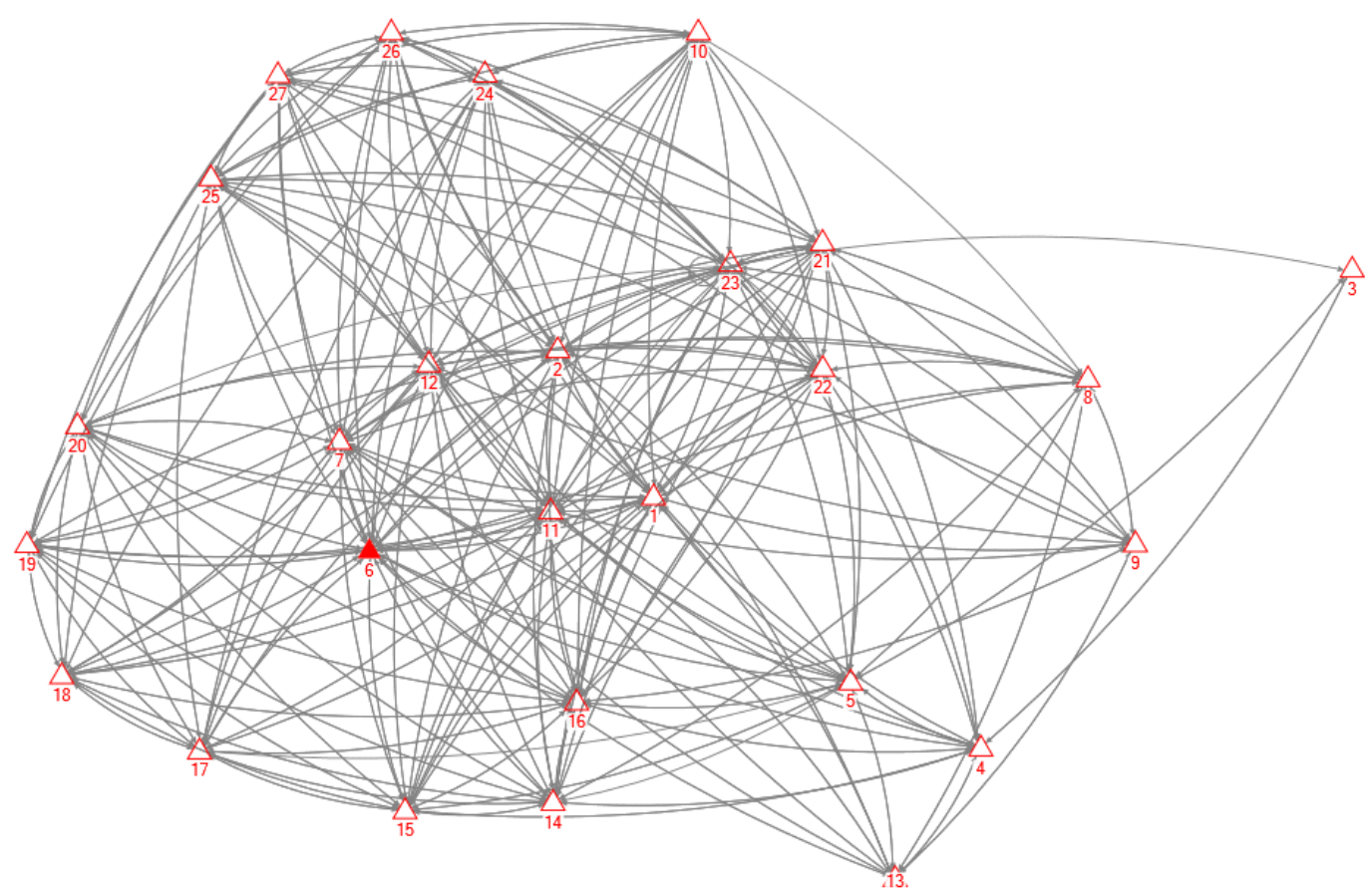

Figure 6 Sociogram of mapping of twenty-seven stakeholder roles to reducing fire-hazard in conservation area. Nodes 1: Head of Mount Ciremai NP; 2: Head of Pasawahan Resort, Mount Ciremai NP; 3: Head of West Java Province Environmental Agency; 4: Head of Kuningan Regency Environmental Agency; 5: Head of Kuningan Botanical Garden; 6: Head of Kuningan Regency Regional Planning Agency; 7: Head of Kuningan Regency Regional Disaster Management Agency; 8: Kuningan Regency Regional Owned Enterprises; 9: Local entrepreneur 1; 10: Local entrepreneur 2; 11: Head of AKAR; 12: Head of Ciremai Forum; 13: Head of Kanopi; 14: Head of Pasawahan Village; 15: Head of Kaduela Village; 16: Head of Padabeunghar Village; 17: Head of Trijaya Village; 18: Head of Setianegara Village; 19: Head of Seda Village; 20: Head of Cibuntu Village; 21: Farmer of Pasawahan; 22. Farmer of Kaduela; 23: Farmer of Padabeunghar; 24: Farmer of Trijaya; 25: Farmer of Setianegara; 26: Farmer of Seda; 27: Farmer of Cibuntu.

Table 3 Degree centrality for twenty-seven nodes to reducing fire-hazard in conservation areas

\begin{tabular}{|c|c|c|c|c|}
\hline Nodes & In-degree & In-degree centrality & Out-degree & Out-degree centrality \\
\hline$\# 11$ & 24 & 0.923 & 25 & 0.961 \\
\hline$\# 1$ & 24 & 0.923 & 24 & 0.923 \\
\hline$\# 7$ & 22 & 0.846 & 23 & 0.884 \\
\hline$\# 2$ & 22 & 0.846 & 22 & 0.846 \\
\hline \#6 & 22 & 0.846 & 22 & 0.846 \\
\hline \#12 & 22 & 0.846 & 22 & 0.846 \\
\hline \#21 & 21 & 0.807 & 20 & 0.769 \\
\hline$\# 22$ & 20 & 0.769 & 20 & 0.769 \\
\hline \#23 & 19 & 0.730 & 20 & 0.769 \\
\hline$\# 16$ & 19 & 0.730 & 19 & 0.730 \\
\hline$\# 14$ & 18 & 0.692 & 17 & 0.653 \\
\hline$\# 15$ & 17 & 0.653 & 17 & 0.653 \\
\hline$\# 5$ & 16 & 0.615 & 16 & 0.615 \\
\hline$\# 24$ & 15 & 0.576 & 15 & 0.576 \\
\hline \#25 & 15 & 0.576 & 15 & 0.576 \\
\hline$\# 26$ & 15 & 0.576 & 15 & 0.576 \\
\hline$\# 27$ & 15 & 0.576 & 15 & 0.576 \\
\hline \#17 & 14 & 0.538 & 15 & 0.576 \\
\hline \#18 & 15 & 0.576 & 14 & 0.538 \\
\hline$\# 20$ & 14 & 0.538 & 15 & 0.576 \\
\hline \#19 & 14 & 0.538 & 14 & 0.538 \\
\hline$\# 10$ & 14 & 0.538 & 14 & 0.538 \\
\hline$\# 4$ & 13 & 0.500 & 13 & 0.500 \\
\hline$\# 8$ & 12 & 0.461 & 11 & 0.423 \\
\hline$\# 13$ & 10 & 0.384 & 10 & 0.384 \\
\hline$\# 9$ & 10 & 0.384 & 10 & 0.384 \\
\hline$\# 3$ & 3 & 0.115 & 2 & 0.076 \\
\hline
\end{tabular}


in making joint responsibilities to managed conservation areas where government official and NGO actors had adjacent influencing score among the actors. Zeb et al. (2019) noted that there could be benefits from improved communication and shared management of natural resources between government institutional and community members.

The node\#11 and node\#1 were the most dominant nodes in out-degree centrality (Table 3 ). Node\#11 has been actively interested in putting out voluntary fire threat in the conservation area of Mount Ciremai since the 1990s (Sunar, 2019). It was also group leaders around MCNP who were well acquainted with the node\#11. While node\#11 was a local NGO, he had extensive contacts with other NGOs and had strong personal approach to community members around MCNP such as being a motivator of 12 nature-loving group in Kuningan district and coordinating annual cleaning action at Mount Ciremai. Node\#1 had the second position on degree centrality, meaning that all nodes were required on public policy and action to minimize fire threat. Community members, who were included on MPA, volunteered to help node\#1, node\#7 (head of Kuningan Regency Regional Disaster Management Agency) and node\#11 to extinguish the fire using conventional sticks to hit the blaze. According to Górriz-Mifsud et al. (2019), no evidence of conservation areas was protected by fire volunteers, recent fire experience, or variation of members profile has been found to influence the form of operation. Figure 7 provided a degree centrality graph for reduction of fire for 27 nodes.

Role is a complex feature of personal status, and whether a person fulfils his/her rights and responsibilities in accordance with his/her position so that the individual can perform a task (Narwoko \& Suyanto, 2015). Node\#11 in the purple circle was the largest size and node\#1 in the dark green circle was the second largest in graph (Figure 7). It means that node\#11 played the greatest role in minimizing fire in conservation areas, followed by node\#1. Node\#2 (head of Pasawahan Resort, Mount Ciremai National Park), node\#6 (head of Kuningan Regency Regional Planning Agency), and node\#12 (head of Ciremai Forum) had the same importance score of degree centrality. Even node\#6 had an important role

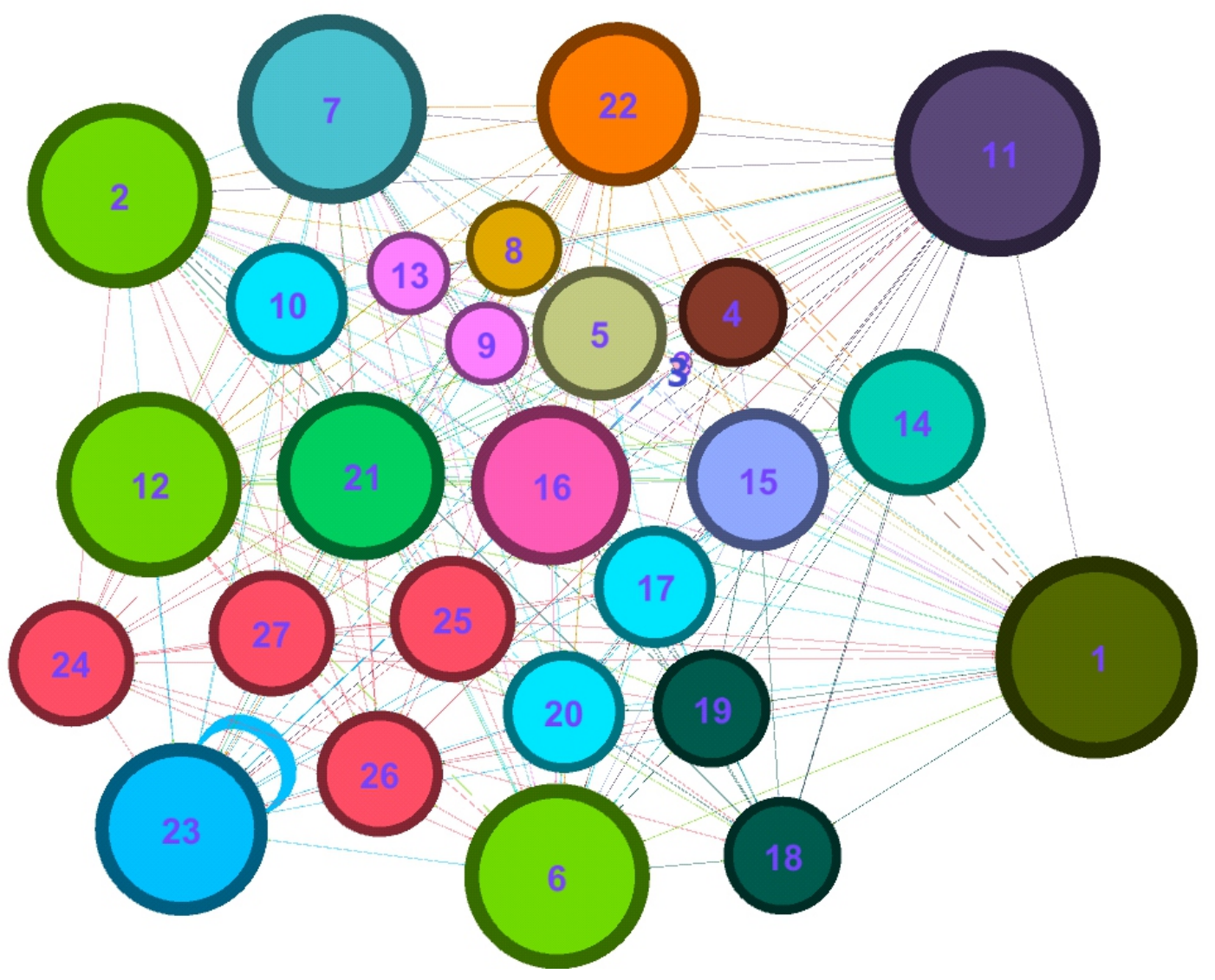

Figure 7 Graph of degree centrality for twenty-seven actors to reducing fire-hazard in conservation areas. Nodes 1: Head of Mount Ciremai NP; 2: Head of Pasawahan Resort, Mount Ciremai NP; 3: Head of West Java Province Environmental Agency; 4: Head of Kuningan Regency Environmental Agency; 5: Head of Kuningan Botanical Garden; 6: Head of Kuningan Regency Regional Planning Agency; 7: Head of Kuningan Regency Regional Disaster Management Agency; 8: Head of Kuningan Regency Regional Owned Enterprises; 9: Local entrepreneur 1; 10: Local entrepreneur 2; 11: Head of AKAR; 12: Head of Ciremai Forum; 13: Head of Kanopi; 14: Head of Pasawahan Village; 15: Head of Kaduela Village; 16: Head of Padabeunghar Village; 17: Head of Trijaya Village; 18: Head of Setianegara Village; 19: Head of Seda Village; 20: Head of Cibuntu Village; 21: Farmer of Pasawahan; 22. Farmer of Kaduela; 23: Farmer of Padabeunghar; 24: Farmer of Trijaya; 25: Farmer of Setianegara; 26: Farmer of Seda; 27: Farmer of Cibuntu. 
on initiative to set up KBG. Node\#6 and community members used to discuss about conservation and rural economic. Node\#2 also played an important role as his standing as a MCNP delegate to community members around conservation area. He often visited the field and listened to complain from the community and gave constructive feedback to raise the revenue from the sector. Lack of knowledge on conservation areas in the view of the community members also occurs because the limited number of MCNP officials spread the conservation area as an important issue. The government officials needed other technological methods to disseminate knowledge, such as using local community members as interpreters by themselves. At least, data showed high degree of node\#1, node\#7, node\#2 and node\#6 centrality which means that government officials were effective nodes in enforcing fire management rules and practices.

Closeness centrality Similar to degree centrality, nodes\#11 (head of AKAR, Aktivitas Anak Rimba), nodes\#1 (head of Mount Ciremai National Park), node\#7 (head of Kuningan Regency Regional Disaster Management Agency), node\#2 (head of Pasawahan Resort, Mount Ciremai National Park), node\#6 (head of Kuningan Regency Regional Planning Agency) and node\#12 (head of Ciremai Forum) were the six highest nodes for closeness centrality. They had a strong obligation to mitigate fire in conservation areas and to recognize the negative impacts of fire on the environment and the people. Actually, the roles of the six nodes on closeness centrality were very good opportunites to tie on reducing fire. Node\#11 and node\#12, as representative of NGO, were very close to community members and able to improve the communication with community. In addition to nodes\#1, three nodes (node\#7, node\#2, and node\#6) as Government officials were important nodes to carrying out management authority of conservation areas. At least, the closeness centrality on six nodes might create network building through trust as a fundamental element in the idea of social capital. Giurca \& Metz (2018) noted that trust, dependency, mutual respect, authority, and common norms must be part of the establishment of this network building. Government officials could engage the NGO to educate the community about the importance of fire prevention. Previous studies had shown that the proximity of settlement to conservation areas would potentially help to reduce the risk of forest fire (Cattau et al., 2016; Sloan et al., 2017; Zeb et al., 2019).

Node\#17 (head of Trijaya Village), node\#10 (local entrepreneur 2), node\#27 (farmer of Cibuntu Village), node\#26 (farmer of Seda Village), node\#25 (farmer of Setianegara Village), and node\#24 (farmer of Trijaya Village) had the same score, it means these six nodes had the same degree of closeness centrality (Table 4). They had frequent contact regarding the same problem of forest fire that occurred in their nearby villages. They took the initiative to create groups of volunteers to extinguish the fire in the forest. Similar to Górriz-Mifsud et al. (2019) findings, volunteer groups were formed in community around the forest when the Mediterranean forest had fire even though they have not yet been able to extinguish forest fire. They also found that the community had a stronger internal or external community bonds, as well as their level of trust, affecting the variety of activities that the groups were conducting and their perception of arsonism in the area. Martínez-torres et al. (2018) noted that fire management was the collection of local community activities as a socioecological and social phenomenon in which there were no single actors, and each player had specific objectives that need reconciliation.

The closeness centrality could greatly benefit government officials as management authorities (head of MCNP and head of KBG) to press the high fire intensity (Figure 8). Management authorities should engage all nodes from NGOs, local entrepreneurs and community members (multi stakeholder) to work together on fire control and to implement of fire public policy in the conservation areas. Public policy enforcement was contingent on the government authorities. Public policy is also an activity established and enforced by legislative authorities of government agencies, with political and financial means to do so. Public policy aims to respond concretely to community problems or needs (Achyar et al., 2015; Panjaitan et al., 2019). When trust has been established in this way, management authorities only needs to encourage stakeholders to overcome the problem of fire. Management institutions must also provide incentives for people who are

Table 4 Closeness centrality for twenty-seven nodes to reducing fire-hazard in conservation areas

\begin{tabular}{rccc}
\hline Nodes & Closeness centrality & Nodes & Closeness centrality \\
\hline 11 & 0.962 & $\# 10$ & 0.702 \\
$\# 1$ & 0.928 & $\# 27$ & 0.702 \\
$\# 7$ & 0.896 & $\# 26$ & 0.702 \\
$\# 2$ & 0.866 & $\# 25$ & 0.702 \\
$\# 6$ & 0.866 & $\# 24$ & 0.702 \\
$\# 12$ & 0.866 & $\# 4$ & 0.666 \\
$\# 22$ & 0.812 & $\# 20$ & 0.666 \\
$\# 21$ & 0.812 & $\# 19$ & 0.666 \\
$\# 16$ & 0.787 & $\# 18$ & 0.666 \\
$\# 23$ & 0.787 & $\# 8$ & 0.634 \\
$\# 15$ & 0.742 & $\# 13$ & 0.619 \\
$\# 14$ & 0.742 & $\# 9$ & 0.619 \\
$\# 5$ & 0.722 & $\# 3$ & 0.433 \\
$\# 17$ & 0.702 & & \\
\hline
\end{tabular}




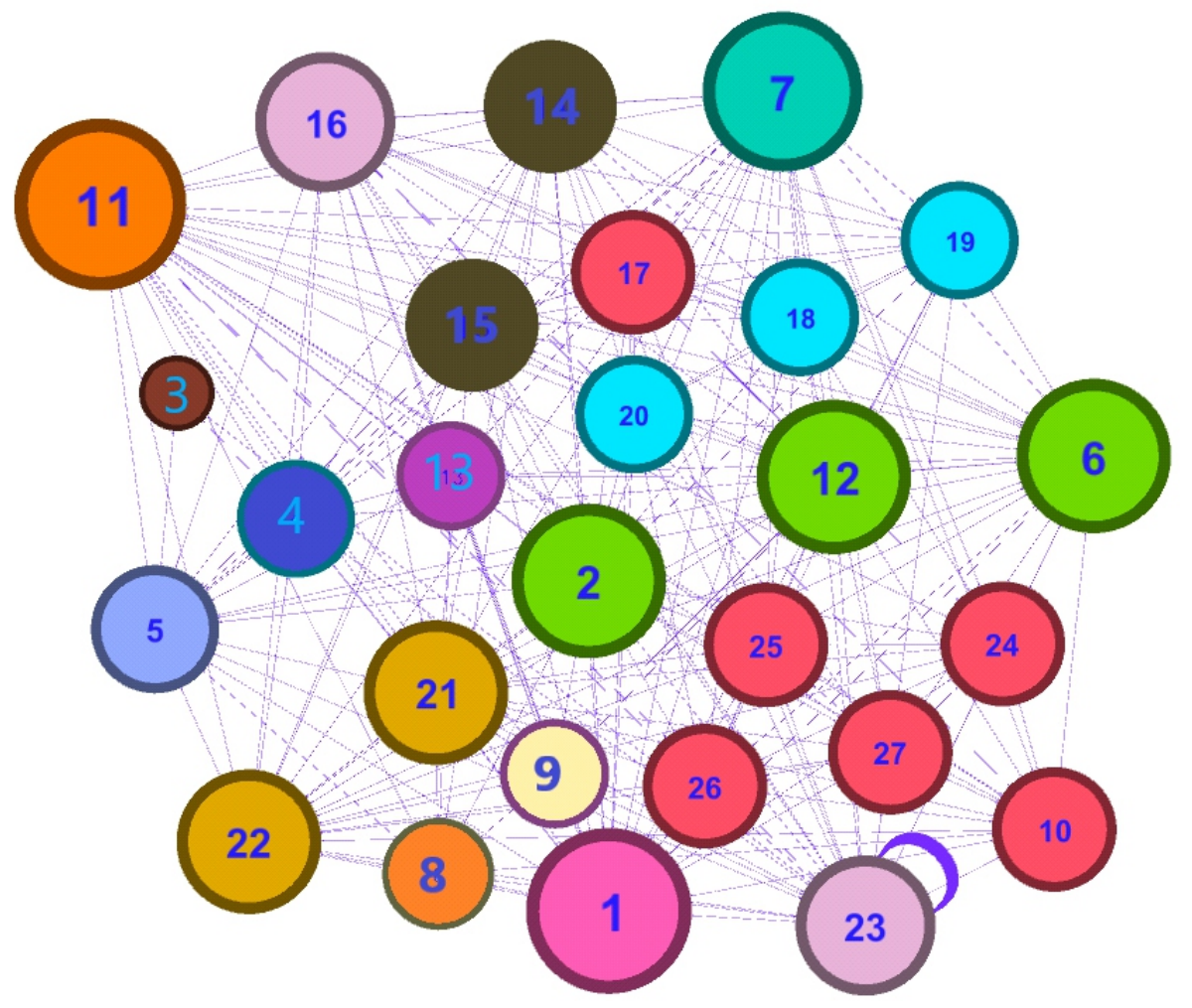

Figure 8 Graph of closeness centrality for twenty-seven actors to reducing fire-hazard in conservations area. Nodes 1: Head of Mount Ciremai NP; 2: Head of Pasawahan Resort, Mount Ciremai NP; 3: Head of West Java Province Environmental Agency; 4: Head of Kuningan Regency Environmental Agency; 5: Head of Kuningan Botanical Garden; 6: Head of Kuningan Regency Regional Planning Agency; 7: Head of Kuningan Regency Regional Disaster Management Agency; 8: Head of Kuningan Regency Regional Owned Enterprises; 9: Local entrepreneur 1; 10: Local entrepreneur 2; 11: Head of AKAR; 12: Head of Ciremai Forum; 13: Head of Kanopi; 14: Head of Pasawahan Village; 15: Head of Kaduela Village; 16: Head of Padabeunghar Village; 17: Head of Trijaya Village; 18: Head of Setianegara Village; 19: Head of Seda Village; 20: Head of Cibuntu Village; 21: Farmer of Pasawahan; 22. Farmer of Kaduela; 23: Farmer of Padabeunghar; 24: Farmer of Trijaya; 25: Farmer of Setianegara; 26: Farmer of Seda; 27: Farmer of Cibuntu.

able to inspire many people in terms of mitigate forest fires. Rewards for communities to reduce fires can be a training program to extinguish fire and other programs to improve the community's economy. Additional warning boards of forest fires in strategic areas (roadside and near settlements in conservation areas) must also be established.

Betweenness centrality A higher betweenness centrality score suggests greater centrality and that the network is regulated by a fairly limited number of nodes around with the highest betweenness score node (Huang et al., 2019). Field data showed that node\#1 and node\#5 as government officials as two the highest for betweenness centrality score. As heads of conservation areas, these two nodes have played a vital role in linking all players within a social network. Node\#11 (head of AKAR, Aktivitas Anak Rimba) had the second highest centrality of betweenness. Node\#11 roles as a mediator of all nodes within this network was still high. To date, both nodes having authority were tried to extinguish the fire by the existence of node\#11. In addition to node\#11, all actors believed that node\#1 and node\#5 were significant persons to be related to as managers authorities. The relative balance of power between the nodes was crucial to ensuring good governance (Purnomo et al., 2018). If fire occurs, they were usually the most liable person to contact. Without good governance, fire occurrence related concerns would easily arise.

The betweenness centrality for 27 nodes revealed that node\#23, (farmer of Padabeunghar Village) as a community member, had significant role as a mediator between the other members of the group (Table 5). Node\#23 lived around two conservation areas and had good relationship with other village farmers. As a mediator, the roles of actor node\#23 reflected that participatory conservation was in good relationship in community level. The category of this actor had indirect relationships with fire danger management policy makers (Nugroho, 2013), but it is concerned with any decisions relevant to the issue. As Aldashev \& Vallino (2019) mentioned, participatory conservation was a powerful idea to built in national and international development initiatives, 
focused on the goal of balancing economic growth with conservation of nature. Besides node $\# 23$ as a farmer or a community member, node\#21 (farmer of Pasawahan Village) and node\#22 (farmer of Kaduela Village) had the same scores. This term means local communities were actively interested in conservation activities.

Purnomo et al. (2018) noted that governance was characterized as how to make and enforce policies and decisions. As Nugroho (2013) said during the policy-making process on the issue, government officials as the main stakeholder have power and high interests. The graph of 27 nodes in betweenness centrality revealed that node\# 1 and node\#5 as the heads of two conservation areas had a powerful to enforce fire policy authority for all nodes, including the

Table 5 Betweenness centrality for twenty-seven nodes to reducing fire-hazard in conservation areas

\begin{tabular}{rccc}
\hline Nodes & Betweenness centrality & Nodes & Betweenness centrality \\
\hline$\# 1$ & 25.953 & $\# 17$ & 2.844 \\
$\# 11$ & 25.719 & $\# 25$ & 2.830 \\
$\# 5$ & 24.599 & $\# 24$ & 2.830 \\
$\# 23$ & 24.296 & $\# 27$ & 2.746 \\
$\# 12$ & 21.917 & $\# 26$ & 2.746 \\
$\# 2$ & 21.456 & $\# 20$ & 2.564 \\
$\# 6$ & 17.688 & $\# 13$ & 2.402 \\
$\# 7$ & 17.613 & $\# 8$ & 2.149 \\
$\# 4$ & 15.889 & $\# 19$ & 2.146 \\
$\# 21$ & 11.702 & $\# 18$ & 2.128 \\
$\# 22$ & 11.526 & $\# 10$ & 1.911 \\
$\# 16$ & 10.856 & $\# 9$ & 1.338 \\
$\# 14$ & 7.765 & $\# 3$ & 0.000 \\
$\# 15$ & 5.671 & & \\
\hline
\end{tabular}

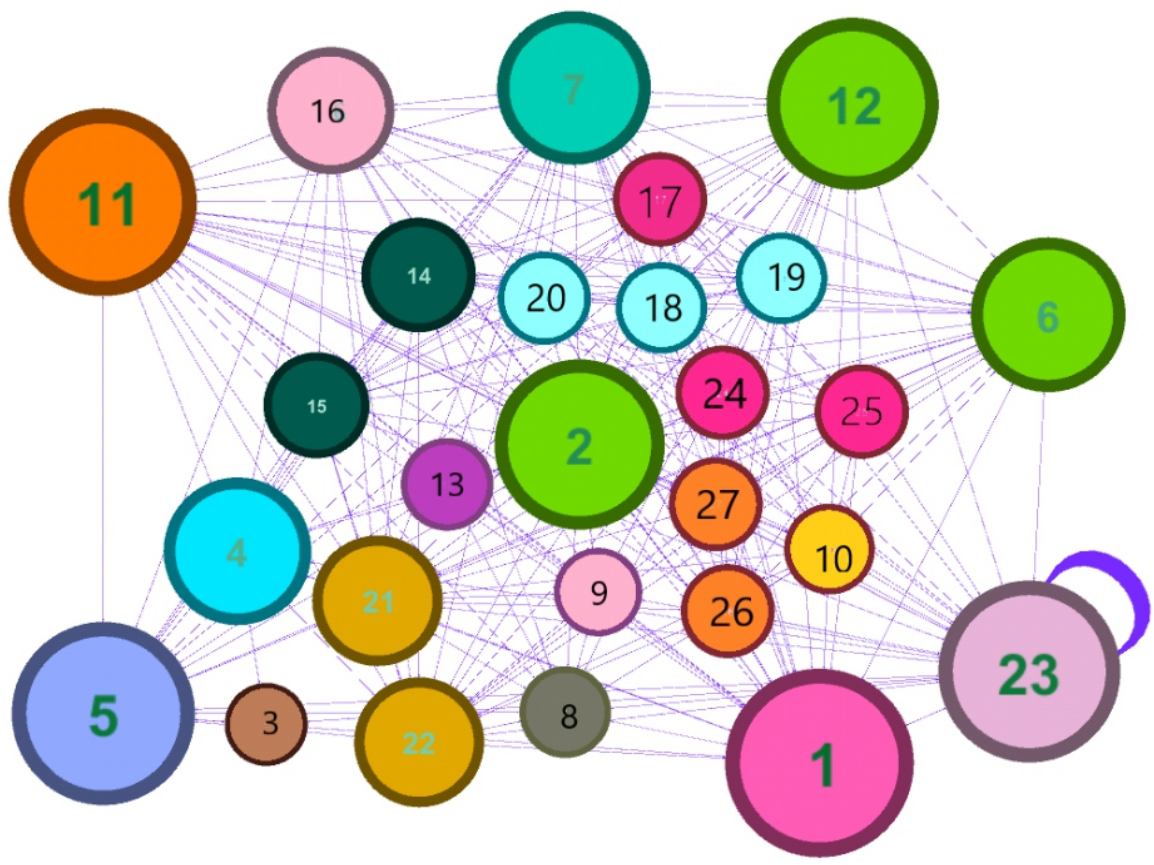

Figure 9 Graph of betweenness centrality for twenty-seven actors to reducing fire-hazard in conservations area. Nodes 1: Head of Mount Ciremai NP; 2: Head of Pasawahan Resort, Mount Ciremai NP; 3: Head of West Java Province Environmental Agency; 4: Head of Kuningan Regency Environmental Agency; 5: Head of Kuningan Botanical Garden; 6: Head of Kuningan Regency Regional Planning Agency; 7: Head of Kuningan Regency Regional Disaster Management Agency; 8: Head of Kuningan Regency Regional Owned Enterprises; 9: Local entrepreneur 1; 10: Local entrepreneur 2; 11: Head of AKAR; 12: Head of Ciremai Forum; 13: Head of Kanopi; 14: Head of Pasawahan Village; 15: Head of Kaduela Village; 16: Head of Padabeunghar Village; 17: Head of Trijaya Village; 18: Head of Setianegara Village; 19: Head of Seda Village; 20: Head of Cibuntu Village; 21: Farmer of Pasawahan; 22: Farmer of Kaduela; 23: Farmer of Padabeunghar; 24: Farmer of Trijaya; 25: Farmer of Setianegara; 26: Farmer of Seda; 27: Farmer of Cibuntu. 
forest fire budget (Figure 9). Both institutions had a budget for mitigate forest fire, fire extinguishing, and post-fire regeneration. Unfortunately, there was limited equipment to extinguish the fire. Human societies that deal with these ecosystems need some resources to adapt to fire disruptions in their settlements. Normally, the fire-fighters welfare state program encompasses the fire cycle process of suppression. Nevertheless, prevention and preparedness and first action were still far away from the duties of firefighters or with possibilities exist (Górriz-Mifsud et al., 2019).

\section{Conclusion}

This research study has obtained network mapping of multi stakeholder to mitigate frequent fires in two conservation areas. Twenty-seven actors or nodes of multi stakeholder played important roles to mitigate fire in conservation areas. They are identified as Government officials, non-governmental organizations, local businessmen, and community members. The network density was more than $50 \%$ (strong relation) but it was still need to improve good relations among all actors to suppress the high fire rate. Node\#11 (head of AKAR, Aktivitas Anak Rimba) played as the most famous actor since node\#11 had a capacity to address the community group around conservation areas. Node\#1 (head of Mount Ciremai National Park) should strengthen his authority to further enforce public policy and involve all actors to contribute to mitigate fire in conservation area. As government officials with the highest score on betweenness centrality, node\#1 and node\#5 (head of Kuningan Botanical Garden) should perform mutual trust to make other actors believe that heads of two conservation areas are a solid team to prevent conservation areas from further devasting burning.

\section{Recommendation}

Two of the management authorities should perform a tight coordination each other such as implementing cooperation agreement to mitigate fire in conservation areas. More intensive environmental control must be undertaken to reach the society around conservation areas, as our study showed that not all people understood the important of conservation area. If necessary, provisions for rewards for individuals or groups who guard against fires and penalties for individuals who use fire carelessly should be implemented stricter.

\section{Acknowledgment}

The authors acknowledge Bapak Ali Jainal, SP, Head of Kuningan Botanical Garden, and Bapak Kuswandono, MP, Head of Mount Ciremai National Park, for research permission. Saintek Scholarship and Ministry of Science and Technology and National Education, Republic of Indonesia, provided this research funding.

\section{References}

Achyar, E., Schmidt-Vogt, D., \& Shivakoti, G. P. (2015). Dynamics of the multi-stakeholder forum and its effectiveness in promoting sustainable forest fire management practices in South Sumatra, Indonesia.
Environmental Development, 13, 4-17. https:/doi.org/ 10.1016/j.envdev.2014.11.002

Aldashev, G., \& Vallino, E. (2019). The dilemma of NGOs and participatory conservation. World Development, 123, 104615. https://doi.org/10.1016/j.worlddev.2019. 104615

Brass, J. (1984). Being in the right place: A structural analysis of individual influence in an organization. Administrative Science Quarterly, 29(4), 518-539. https://doi.org/10.2307/2392937

Cattau, M. E., Harrison, M. E., Shinyo, I., Tungau, S., Uriarte, M., \& DeFries, R. (2016). Sources of anthropogenic fire ignitions on the peat-swamp landscape in Kalimantan, Indonesia. Global Environmental Change, 39, 205-219. https://doi.org/ 10.1016/j.gloenvcha.2016.05.005

Eckerberg, K., \& Buizer, M. (2017). Promises and dilemmas in forest fire management decision-making: Exploring conditions for community engagement in Australia and Sweden. Forest Policy and Economics, 80, 133-140. https://doi.org/10.1016/j.forpol.2017.03.020

Edwards, R. B., Naylor, R. L., Higgins, M. M., \& Falcon, W. P. (2020). Causes of Indonesia's forest fires. World Development, 127, 104717. https://doi.org/10.1016/j. worlddev.2019.104717

Febriandhika, A. I., Rahman, C. T., Ramdani, F., \& Saputra, M. C. (2018). Tangible landscape: Simulation of estimation of wildfire spread in Arjuno Mountain Tahura R. Soerjo Region. 4th International Symposium on Geoinformatics, 1-8. https://doi.org/10.1109/ISYG. 2018.8611830

Fischer, A. P., Korejwa, A., Koch, J., Spies, T., Olsen, C., White, E., \& Jacobs, D. (2013). Using the forest, people, fire agent-based social network model to investigate interactions in social-ecological systems. Society for Applied Anthropology, 35(1), 8-13.

Freeman, L. (1977). A set of measures of centrality based on betweenness. Sociometry, 40(1), 35-41. https://doi.org/ 10.1111/j.1468-2494.1993.tb00590.x

Giurca, A., \& Metz, T. (2018). A social network analysis of Germany's wood-based bioeconomy: Social capital and shared beliefs. Environmental Innovation and Societal Transitions, 26, 1-14. https://doi.org/10.1016/j.eist.20 17.09.001

Górriz-Mifsud, E., Burns, M., \& Marini Govigli, V. (2019). Civil society engaged in wildfires: Mediterranean forest fire volunteer groupings. Forest Policy and Economics, 102, 119-129. https://doi.org/10.1016/j.forpol.2019. 03.007

Hadiana, A. I., \& Witanti, W. (2017). Analisis jejaring sosial menggunakan Social Network Analysis untuk membantu 
social CRM bagi UMKM di Cimahi. Saintiks FTIK UNIKOM, VI.29-VI.36.

Hadiprasetya, Y. (2009). Identifikasi faktor penyebab kebakaran hutan dan upaya penanggulangannya di Taman Nasional Gunung Ciremai, Jawa Barat. Bogor: Bogor Agricultural University.

Huang, M., Wang, Z., \& Chen, T. (2019). Analysis on the theory and practice of industrial symbiosis based on bibliometrics and social network analysis. Journal of Cleaner Production, 213, 956-967. https://doi.org/10. 1016/j.jclepro.2018.12.131

[KRK] Kebun Raya Kuningan. (2019). Laporan Tahunan. Kuningan: Kebun Raya Kuningan

Lestari, K. G., Putra, E. I., \& Matangaran, J. R. (2019). Identifying forest fires causes in Kawah Kamojang Nature Reserve (Mount Guntur), Garut, West Java. IOP Conference Series: Earth and Environmental Science, 394(1). https://doi.org/10.1088/1755-1315/394/1/0120 42

Lovric, M., Da Re, R., Vidale, E., Pettenella, D., \& Mavsar, R. (2018). Forest policy and economics social network analysis as a tool for the analysis of international trade of wood and non-wood forest products. Forest Policy and Economics, 86, 45-66. https://doi.org/10.1016/j.forpol. 2017.10.006

Manik, Y. M., Sutanta, H., \& Diyono, D. (2018). Analisis pemangku kepentingan dan peranannya dalam pemanfaatan informasi geospasial di pemerintah daerah menggunakan metode social network analysis. Seminar Geomatika National: Inovasi Teknologi Penyediaan Informasi Geospasial untuk Pembangunan Berkelanjutan, 409-418.

Martínez-torres, H. L., Pérez-salicrup, D. R., Castillo, A., \& Ramirez, M. I. (2018). Fire management in a natural protected area: What do key local actors say? Human Ecology, 46, 515-528.

Milovanović, S., Bogdanović, Z., Labus, A., Barać, D., \& Despotović-zrakić, M. (2019). An approach to identify user preferences based on social network analysis. Future Generation Computer Systems, 93, 121-129. https://doi.org/10.1016/j.future.2018.10.028

Narwoko, J. D., \& Suyanto, B. (2015). Sosiologi. Teks pengantar dan terapan (4th ed.). Jakarta: Prenadamedia Group.

Nugroho, B. (2013). Stakeholders analysis of policy-making process: The case of timber legality policy on private. Jurnal Manajemen Hutan Tropika, 19(2), 156-162. https://doi.org/10.7226/jtfm.19.2.156

Panjaitan, R. B., Sumartono, S., Sarwono, S., \& Saleh, C. (2019). The role of central government and local government and the moderating effect of good governance on forest fire policy in Indonesia. Benchmarking, 26(1), 147-159. https://doi.org/10.1108/ BIJ-12-2017-0336

Pinto, C., Viegas, D., Almeida, M., \& Raposo, J. (2017). Fire whirls in forest fi res: An experimental analysis. Fire Safety Journal, 87, 37-48. https://doi.org/10.1016/ j.firesaf.2016.11.004

Pryke, S. D. (2004). Analysing construction project coalitions: exploring the application of social network analysis. Construction Mangement and Economics, 22, 787-797. https://doi.org/10.1080/0144619042000 206533

Purnomo, H., Okarda, B., Ayu, A., Ali, M., Achdiawan, R., Kartodihardjo, H., Pacheco, P., \& Juniwaty, K. S. (2018). Reducing forest and land fires through good palm oil value chain. Forest Policy and Economics, 91, 94-106. https://doi.org/10.1016/j.forpol.2017.12.014

Purnomo, H., Shantiko, B., Sitorus, S., Gunawan, H., Achdiawan, R., Kartodihardjo, H., \& Dewayani, A. A. (2017). Fire economy and actor network of forest and land fires in Indonesia. Forest Policy and Economics, 78, 21-31.https://doi.org/10.1016/j.forpol.2017.01.001

Rosales-Rueda, M., \& Triyana, M. (2018). The persistent effects of early-life exposure to air pollution: Evidence from the Indonesian forest fires. Journal of Human Resources, 54(4), 0117-8497R1. https://doi.org/10.3368/ jhr.54.4.0117.8497r1

Scott, J. (2017). Social network analysis (M. Steele (Ed.)(4th ed.). California: SAGE Publications.

Singgalen, Y., Sasongko, G., \& Wiloso, P. G. (2019). Ritual capital for rural livelihood and sustainable tourism development in Indonesia. Jurnal Manajemen Hutan Tropika, 25(2), 115-125. https://doi.org/10.7226/ jtfm.25.2.115

Sloan, S., Locatelli, B., Wooster, M. J., \& Gaveau, D. L. A. (2017). Fire activity in Borneo driven by industrial land conversion and drought during El Niño periods, 1982 2010. Global Environmental Change, 47, 95-109. https://doi.org/10.1016/j.gloenvcha.2017.10.001

Sunar, S. (2019). HUT ke-29 LSM AKAR, Bupati Kuningan berpesan jangan tinggalkan sampah di gunung. Nuansa Post. Retrieved from https://www.nuansapost.com/ 2019/12/hut-ke-29-lsm-akar-bupati-kuningan.html

[TNGC] Taman Nasional Gunung Ciremai. (2018). Data statistik Balai Taman Nasional Gunung Ciremai Tahun 2017 (Issue 1).

Tian, X., Zhao, F., Shu, L., \& Wang, M. (2013). Distribution characteristics and the influence factors of forest fires in China. Forest Ecology and Management, 310, 460-467. https://doi.org/10.1016/j.foreco.2013.08.025 
Wasserman, S., \& Faust, K. (1994). Social network analysis: Methods and applications (Vol 1). Cambridge: Cambridge University Press.

Whitmore, T. (1988). Tropical rain forest of the far east (2nd ed). Oxford: Oxford University Press.

Yeung, J. (2020, January 14). Australia's deadly wildfires are showing no signs of stopping. Here's what you need to know. CNN. Retrieved from https://edition.cnn.com/ 2020/01/01/australia/australia-fires-explainer-intl-hnkscli/index.html

Zeb, A., Hamann, A., Armstrong, G. W., \& AcunaCastellanos, D. (2019). Identifying local actors of deforestation and forest degradation in the Kalasha valleys of Pakistan. Forest Policy and Economics, 104, 56-64.https://doi.org/10.1016/j.forpol.2019.04.005 